\title{
Penerapan Model Pembelajaran Menggunakan Pendekatan Saintifik di Sekolah Dasar
}

\author{
Ina Magdalena ${ }^{1}$, Dewi Rachma Lestari ${ }^{2}$, Aniq Insyirah ${ }^{3}$, \& Siti Khoiriah ${ }^{4}$ \\ Universitas Muhammadiyah Tangerang \\ inapgsd@gmail.com ${ }^{1}$,dewirachmales@gmail.com²
}

\begin{abstract}
The study aims to describe the application of scientific learning models conducted at SDN Palsari 3. Thus study uses a qualitative approach with descriptive research type. The subjects in this study were teachers and students in elementary schools. Data collection techniques using observation, intervierws, and data analysis. Data analysisechniques used are the miles and buberman modelswich include data collection,data reduction, and data presentation. The validity test of the data used is the reliability test whichh is done by triangulation of sources. The results of the study indicate that the teacher has implemented a scientific approach to the maximum starting from the planning, implementation, and assesment in the learning process. The steps of the activities in the application of scientific learning which includes observing, asking, trying, reasoning and communicating activities that have been implemented by the teacher. Student activities in the learning process show that students have been to be active, enthusiastic and motivated.
\end{abstract}

Keywords: Learning Model, Scientific Approach

\begin{abstract}
Abstrak: Penelitian ini bertujuan untuk mendeskripsikan tentang penerapan model pembelajaran saintifik yang dilakukan di SDN Palasari 3. Penelitian ini menggunakan pendekatan kualitatif dengan jenis penelitian deskriptif. Subyek dalam penelitian ini adalah guru dan siswa yang ada di sekolah dasar. Teknik pengumpulan data menggunakan observasi, wawancara, dan analisis data. Teknik analisis data yang digunakan adalah model Miles dan Huberman yang meliputi pengumpulan data, reduksi data, dan penyajian data. Uji keabsahan data yang digunakan adalah uji kredibilitas yang dilakukan dengan cara triangulasi sumber. Hasil penelitian menujukkan bahwa guru sudah menerapkan pendekatan saintifik secara maksimal mulai dari perencanaan, pelaksanaan, dan penilaian dalam proses pembelajaran. Langkah-langkah kegiatan dalam penerapan pembelajaran saintifik yang meliputi kegiatan mengamati, menanya, mencoba, menalar, dan mengkomunikasikan sudah dilaksanakan oleh guru. Aktifitas siswa dalam peoses pembelajaran menunjukan bahwa siswa sudah terlihat secara aktif, antusias dan termotivasi.
\end{abstract}

Kata Kunci : Model Pembelajaran, Pendekatan Saintifik

Islamika : Jurnal Keislaman dan Ilmu Pendidikan

Volume 2, Nomor 1, Januari 2020; 140-147

https:// ejournal.stitpn.ac.id/index.php/islamika 


\section{PENDAHULUAN}

Pendidikan adalah usaha sadar yang bertujuan untuk mengembangkan kualitas manusia sebagai suatu kegiatan yang sadar akan tujuan. Pendidikan mempunyai peran yang sangat dalam kehidupan karena melalui pendidikan karakter dan sumber daya manusia dapat dibentuk menjadi lebih baik. Pendidikan mempunyai tugas yang sangat penting dalammenyiapkan sumber daya manusia untuk pembangunan yang berkualitas di masa depan.

Upaya peningkatan kualitas pendidikan terus-menerus dilakukan baik secara konvensional maupun inovatif. Hal tersebut lebih terfokus lagi setelah di amanatkan bahwa tujuan pendidikan nasional adalah untuk meningkatkan mutu pada setiap jenis dan jenjang pendidikan. Untuk kepentingan tersebut diperlukan perubahan yang cukup mendasar dalam sistem pendidikan nasional. Perubahan mendasar tersebut berkaitan dengan kurikulum yang dengan sendirinya menuntut dan mempersyaratkan berbagai perubahan pada komponen-komponen pendidikan lain.

Berkaitan dengan kurikulum, berbagai pihak menganalisis dan melihat perlunya diterapkan kurikulum berbasis kompotensi sekaligus berbasis karakter yang dapat membekali peserta didik denganberbagai sikap dan kemampuan yang sesuai dengan tuntutan perkembangan zaman. Oleh karena itu merupakan langkah yang positif ketika pemerintah (Mendikbud) merevitalisasi pendidikan karakter dalam seluruh jenis dan jenjang pendidikan, terutama dalampengembangan kurikulum 2013.

Kurikulum 2013 lebih ditekankan pada pendidikan karakter, terutama pada tingkat dasar yang akan menjadi fondasi bagi tingkat berikutnya. Kurikulum ini adalah pengembangan dari kurikulum yang telah ada sebelumnya, baik Kurikulum berbasis kompotensi yang telah di rintis pada 2004 maupun kurikulum tingkat satuan pendidikan pada tahun 2006. Kurikulum 2013 menekankan pada dimensi pedagogik modern dalam pembelajaran yaitu dengan menggunakan pendekatan ilmiah (scientific approach).

Berdasarkan hasil observasi dan wawancara awal yang dilakukan terhadap guru di SD Palasari 3, peneliti menemukan beberapa kendala yang terkait dengan penerapan pendekatan saintifik pada siswa/siswi SDN Palasari 3. Latar belakang 
peneliti melakukan penelitian di SDN Palasari 3 merupakan salah satu sekolah yag kami lakukan observasi untuk mengetahui tentang penerapan pendekatan saintifik.

Adanya pergantian kurikulum yaitu dari kurikulum KTSP menjadi kurikulum 2013 ternyata membawa dampak yang sangat besar bagi guru terutama dalam memberikan pelajaran. Guru mengatakan guru merasa kesulitan dengan adanya pergantian kurikulum KTSP menjadi kurikulum 2013, karena dala pelaksanaan kurikulum 2013 gru dituntut untuk dapat memfasilitasi dan memotivasi siswa dalam proses pembelajaran karena pendekatan saintifiklebih menekankan pada pendekatan ilmiah yang dapat mamicu siswa untuk dapat berpikir secara ilmiah serta dapat berperan secara aktif dalam proses pembelajaran.

Guru juga mengatakan bahwa penerapan pendekatan saintifik belum dapat diterapkan secara maksimal, hal tersebut disebabkan karena adanya keterbatasan waktu dalam menyampaikan materi. Guru membutuhkan waktu yang lebih banyak dalam menyampaikan materi karena materi pembelajaran yang ada pada kurikulum 2013 mempunyai cakupan yang sangat luas sehingga materi yang disampaikan tidak dapat selesai dalam satu kali pertemuan.

Tujuan utama dari penelitian ini untuk mengetahui penerapan pendekatan saintifik pada siswa/siswi di SDN Palasari 3 untuk mengetahui kendala yang di alami guru pada saat menerapkan pendekatan saiktifik di sekolah.

\section{METODE PENELITIAN}

\section{Jenis Penelitian}

Jenis penelitian yang digunakan adalah penelitian deskriptif kualitatif.

\section{Waktu dan Tempat Penelitian}

Penelitian dilaksanakan selama hampir 2 minggu yaitu dari tanggal 11 November sampai 22 November 2019 di SDN Palasari 3

\section{Subjek Penelitian}

Subjek penelitian merupakan seseorang atau sesuatu ang darinya diperoleh keterangan dan untuk selanjutnya disebut informan. Penelitian ini juga mengambil 
informan kunci. Maka dalam subjek penelitian ini adalah guru dan siswa Sekolah Dasar Negeri Palasari 3. Yang didasarkan pada alasan guru dan siswa merupakan pelaksan utama dalam pembelajaran.

\section{Data, Instrumen, dan Teknik Pengumpulan Data}

Teknik pengumpulan data dengan menggunakan instrumen observasi, wawancara, dan dokumentasi. Teknik pengumpulan data yang bermacam-macam (triangulasi data), pengumpulan data dilakukan secara terus-menerus sampai datanya jenuh.

\section{Teknik Analisis Data}

Teknik analisis data pada penelitian ini menggunakan metode analisis deskriptif kualitatif. Analisis data kualitatif dengan proses mencari dan menyusun secara sistematisdata yang diperoleh dari hasil wawancara, catatan lapangan, dan bahan-bahan lain.

Teknik analisis data penelitian di lakukan dengan reduksi data enyajian data dan penarikan kesimpulan. Reduksi data yaitu proses pemilihan, pemutusan perhatian pada penyederhanaan, pengbstrakan, dan transformasi data "kasar" yang muncul dari catatan di lapangan. Penyajin data yaitu penyusunan sekelompok informasi yang memberi kemungkinan adanya penarikan kesimpulan dan pengembalian tindakan. Penarikan kesimpulan yaitu di ungkapkan makna dari data yang di kumpulkan.

\section{HASIL PENELITIAN DAN PEMBAHASAN}

SDN Palasari 3 merupakan salah satu SD Adiwiyata yang ada di Kecamatan Legok. SDN Palasari 3 telah memiliki akreditasi B. Penetapan lokasi penelitian di SDN Palasari 3 ini dikarenakan salah satu sekolah yng sudah menggunakan kurikulum 2013 dan menerapkan pendekatan saintifik dalam setiap proses pembelajaran.

Hasil penelitian menunjukan bahwa penerapan model pembelajaran yang menggunakan pendekatan saintifik ini belum terlaksana dengan baik di karenakan adanya sebuah kesulitan dalam menerapkan nya. Jadi sebelum guru menggunakan 
pendekatan saintifik ini di sekolah harusnya seorang guru mempelajari dengan baik dan membuat rancangan seperti silabus atau RPP pembelajaran terlebih dahulu sebelum menerapkannya.

Manfaat yang akan di dapat diperoleh oleh guru dalam menggunakan pendekatan saintifik dalam proses pembelajaran yaitu dengan adanya pendekatan sintidik siswa menjadi lebih aktif, kreatif, pembelajaran semakin lebih menyenangkan, siswa dapat berpikir lebih ilmiah dan karakter siswa semakin di bentuk.

Pada tahap pelaksanaan guru sudah menerapkan pendekatan saintifik yaitu (mengamati, menanya, mengumpulkan informasi/mencoba, menalar/mengasosiasikan, dan mengkomunisasikan)dengan optimal. Dalam tahap pelaksanaan ini guru sudah mampu menempatkan diri sebagai fasilitator dan mediator yang baik dlam proses pembelajaran agar siswa lebih termotivasi dalam mengikuti pembelajaran. Hal ini sejalan dengan prinsip pengelolaaan pembelajaran menurut Trianto (2011: 154) yaitu pengelolaan pembelajaran dapat optimal apabila guru mampu menempatkan dirirnya dalam keseluruhan proses, guru harus menempatkan diri sebagai fasilitator dalam proses pembelajaran yang dilakukan oleh siswa. ${ }^{1}$

Pembelajaran dengan pendekatan saintifik adalah proses pembelajaran yang dirancang sedemikian rupa agar peserta didik secara aktif mengonstruk konsep, hukum atau prinsip melalui tahapan-tahapan mengamati (untuk mengidentifikasi atau menemukan masalah), merumuskan masalah, mengajukan atau merumuskan hipotesis, mengumpulkan data dengan berbagai teknik, menganalisis data, menarik kesimpulan dan mengomunikasikan konsep, hukum atau prinsip yang "ditemukan".

Pendekatan saintifik dimaksudkan untuk memberikan pemahaman kepada peserta didik dalam mengenal, memahami berbagai materi menggunakan pendekatan ilmiah, bahwa informasi bisa berasal dari mana saja, kapan saja, tidak bergantung pada informasi searah dari guru. Oleh karena itu kondisi pembelajaran yang

\footnotetext{
${ }^{1}$ Trianto. (2011). Desain Pengembangan Pembelajaran . Jakarta: kencana Predana Media Group.
} 
diharapkan tercipta diarahkan untuk mendorong peserta didik dalam mencari tahu dari berbagai sumber melalui observasi, dan bukan hanya diberi tahu.

Penerapan pendekatan saintifik dalam pembelajaran melibatkan keterampilan proses seperti mengamati, mengklasifikasi, mengukur, menjelaskan, dan menyimpulkan. Dalam melaksanakan proses-proses tersebut, bantuan guru diperlukan. Akan tetapi bantuan guru tersebut harus semakin berkurang dengan semakin bertambah dewasanya siswa atau semakin tingginya kelas siswa. Metode saintifik sangat relevan dengan tiga teori belajar yaitu teori Bruner, teori Piaget, dan teori Vygotsky. ${ }^{2}$

Proses pembelajaran dengan berbasis pendekatan ilmiah harus dipandu dengan kaida-kaidah pendekatan ilmiah. Pendekatan ini bercirikan penonjolan dimensi pengamatan, penalaran, penemuan, pengabsahan, dan penjelasan tentang suatu kebenaran. Dengan demikian, proses pembelajaran harus dilaksanakan dengan dipandu nilai-nilai, prinsip-prinsip, atau kriteria ilmiah. Proses pembelajaran disebut ilmiah jika memenuhi kriteria seperti berikut ini :

Kendala yang di alami oleh guru dalam menerapkan pendekatan saintifik antara lain: (1) kendala pertama, guru merasa kesulitan pada saat membuat perencanaan karena materi yang ada dalam kurikulum 2013 mempunyai cakupan yang sangat luas, (2) kndala kedua, untuk tahap pelaksanaan guru membutuhkan waktu yang lebih banyak dalam menyampaikan materi pembelajaran, (3) kendala ketiga, yang dialami guru yaitu saat melakukan penilaian, guru membutuhkan waktu yang lebih banyak dalam melakukan penilaian karena penilaian yang dilakukn melibatkan tiga aspek yaitu aspek sikap, aspek pengetahuan, dan aspek keterampilan, (4) kendala keempat, gurumemiliki kendala dalam penggunaan software.terkait dengan kendala pertama yang dialami guru maka upaya atau solusi yang dilakukan guru yaitu dengan konsultasi sesama guru dan mencari lagi sumber-sumber yang mendukung serta merangkum semua materi yang cakupannya dianggap terlalu luas.

Dari paparan hasil penelitian diatas, dapat diamati bahwa guru sudah dapat menerapkan pendekatan saintifik dengan baik selama proses pembelajaran. Jika

${ }^{2}$ Sudrajat, Akhmad. (2013). Pendekatan Saintifik dalam Proses Pembelajaran. 
beberapa kendala diatas dapat diatasi dengan baik makan penerapan pendekatan saintifik ini dapat diterapkan dengan lebih baik lagi.

\section{KESIMPULAN DAN SARAN}

\section{Kesimpulan}

Berdasarkan paparan diatas maka kesimpulan yang dapat diambil antara lain:

1. Guru sudah memahami teori tentang pendekatan saintifik, baik guru bidang ataupun guru kelas sudah mulai memahami tentang penerapan model pembelajaran saintifik di sekolah dasar ini yang akan di terapkan di sekolah.

2. Perencanaan, pelaksanaan, dan penilaian yang terkait dengan pendekatan saintifik sudah dilakukan guru dengan optimal meskipun guru masih membutuhkan waktu yang cukup banyak dalam melakukan perencanaan, pelaksanaan, dan penilaian, tetapi sejauh ini guru selalu berusaha melakukan yang terbaik agar ketiga tahap tersebut terjalan dengan optimal.

3. Guru menglami beberapa kendala dalam menerapkan pendekatan saintifik selama proses pembelajaran. Kendala pertamayaitu guru merasa kesulitan pada saat membuat perencnaan karena materi yang ada dalam kurikulum 2013 mempunyai cakupan yng sangat luas.

\section{Saran}

Perlu adanya diskusi lebih lanjut antara kepala sekolah dengan guru untuk membahas kendala-kendala yang dialami guru selama menerapkan pendekatan saintifik guna memudahkan guru dalam mengatasi kendala yang ada upaya-upaya yang diberikan sebelumnya belum dapat mengatasi kendala yang ada. 


\section{DAFTAR PUSTAKA}

Daryanto. (2014). Pembelajarn tematik , Terpadu, Terintegrasi Kurikulum 2013. Yogyakarta: Gava Media

Daryanto. (2014). Pendekatan pembelajaran Saintifik kurikulum 2013. Yogyakarta: Gava Media.

Hosnan. (2014). Pendekatan Saintifik dan Konteksual dalam Pembelajaran Abad 21. Bogor: Ghalia Indonesia.

Sudrajat, Akhmad. (2013). Pendekatan Saintifik dalam Proses Pembelajaran.

Trianto. (2011). Desain Pengembangan Pembelajaran . Jakarta: kencana Predana Media Group. 